Discussion Paper No. 06-023

Do Spillovers Stimulate Incremental or Drastic Product Innovations? Hypotheses and Evidence from German Establishment Data

Uwe Jirjahn and Kornelius Kraft

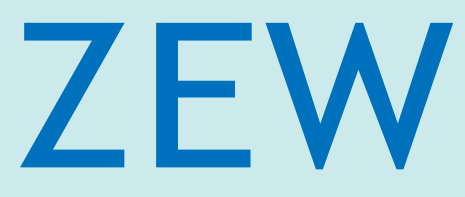

Zentrum für Europäische Wirtschaftsforschung $\mathrm{GmbH}$ Centre for European Economic Research 
Discussion Paper No. 06-023

\title{
Do Spillovers Stimulate Incremental or Drastic Product Innovations? Hypotheses and Evidence from German Establishment Data
}

\author{
Uwe Jirjahn and Kornelius Kraft \\ Download this ZEW Discussion Paper from our ftp server: \\ ftp://ftp.zew.de/pub/zew-docs/dp/dp06023.pdf
}

Die Discussion Papers dienen einer möglichst schnellen Verbreitung von neueren Forschungsarbeiten des ZEW. Die Beiträge liegen in alleiniger Verantwortung der Autoren und stellen nicht notwendigerweise die Meinung des ZEW dar.

Discussion Papers are intended to make results of ZEW research promptly available to other economists in order to encourage discussion and suggestions for revisions. The authors are solely responsible for the contents which do not necessarily represent the opinion of the ZEW. 


\section{Non-technical Summary}

R\&D expenditures are a classical example for spillover effects. Information on innovation activities leaks out to competitors and affects their productivity and profitability. Accordingly spillovers have two sides: On the one hand spillovers act like a positive externality increasing the efficiency of the innovation process. On the other hand the own innovation output of a firm in question is also partly transmitted to competitors.

The literature does not discuss, whether all kinds of innovations are affected by spillovers. In particular there exists no study that disentangles innovations into incremental and drastic innovations. In our paper we analyse the impact of spillovers from rivals on innovations with differing degrees of newness. The main research hypothesis is that firms have better access to information that is related to their current research but have difficulties with applying knowledge that comes form areas they are not familiar with.

We use a sample of manufacturing establishments in Germany with detailed information on the type of innovation. Incremental product innovations are captured by follow-up products, qualitatively improved products and products with additional functions. Drastic innovations are covered by patent applications and the introduction of completely new products. Controlling for various other possible influences, we find that spillovers stimulate incremental but not drastic innovations. These results support our hypothesis that establishments face difficulties in using knowledge from areas they are not familiar with. The firms use spillovers primarily for innovations that are closely related to their existing activities. R\&D cooperations help to some extent to solve the problems in using spillovers for drastic innovations.

We do not find evidence that the firms' own R\&D efforts facilitate the use of external knowledge. According to our results they are rather substitutes. Establishments with high 
innovative activities are close to the frontier of technology and product development. Since they have less to learn from others, outside knowledge is of lower importance to them. 


\title{
Do Spillovers Stimulate Incremental or Drastic Product Innovations? Hypotheses and Evidence from German Establishment Data
}

\author{
Uwe Jirjahn $^{a}$ and Kornelius Kraft ${ }^{b}$
}

March 2006

\begin{abstract}
We estimate the determinants of various types of product innovation. Knowledge spillovers from rivals have a positive impact on incremental innovations. This impact is largely independent of the participation in R\&D cooperations. Spillovers exert no such independent influence on drastic innovation activities. The results support the hypothesis that establishments face difficulties in using knowledge that comes from areas they are not familiar with. Establishments exploit spillovers for incremental innovations rather than for drastic innovations. To a limited degree $R \& D$ cooperations can help to overcome the difficulties in using spillovers for drastic innovations. Furthermore, our estimates provide evidence that a firm's own R\&D effort and the use of outside information are substitutive.
\end{abstract}

JEL Classification: L15, L60, O31, O32.

Key Words: New Products, Patents, Spillovers, Learning, R\&D

a University of Hanover, Germany

b University of Dortmund and ZEW Mannheim, Germany 


\section{Introduction}

Knowledge spillovers play a key role in economic development for several reasons. If the technological knowledge produced by individual firms spreads industry-wide, productivity throughout the whole industry is enhanced. Endogenous growth literature assumes that this implies an aggregate production function which exhibits increasing returns to scale allowing sustained long-run growth (Romer, 1986; Grossman and Helpman, 1990). Empirical research confirms that a substantial part of total productivity growth can be explained by inter- and intra-industry knowledge spillovers (Sena, 2004).

Furthermore, spillovers may have an indirect impact on economic development as they influence the incentives to engage in innovative activities. The firm's own innovations in turn influence both its productivity and profitability (Geroski, 1991; Geroski, Machin and Van Reenen, 1993; Hanel and St-Pierre, 2002). However, spillovers can weaken or strengthen the incentives to undertake innovative activities. If the knowledge accumulated in a firm spills over to other firms, the firm may under-invest in innovative activities as it is unable to fully appropriate returns from those activities (Arrow 1962). On the other hand, spillover effects may provide additional incentives to pursue own innovative projects if this enhances the absorptive capacity to assimilate and exploit existing knowledge from other firms. Following an influential paper by Cohen and Levinthal (1989), a widespread view is that a firm's own R\&D effort increases its absorptive capacity.

Finally, the number of inter-firm strategic alliances increased dramatically during the 1990s. R\&D cooperations among firms are a substantial part of these alliances (Caloghirou, Ioannides and Vonortas, 2003). Starting with the seminal paper by d'Aspremont and Jacquemin (1988), a substantial theoretical literature has examined the impact of spillovers on such cooperations (de Bondt, 1996). While early contributions treated spillovers as exogenous determinants, recent analyses stress that the use of spillovers depends on whether or not firms form cooperative agreements (Katsoulacos and Ulph, 1998; Kamien and Zang, 2000). 
Despite the generally recognized importance of knowledge spillovers, economic literature is essentially silent on the type of innovation stimulated by spillovers. To date, there has been almost no econometric study that examines whether or not a firm can use the knowledge from other firms for all kinds of innovations. In this paper, we consider product innovations differing in their degree of newness to the adopting firms. We investigate the impact of spillovers from rivals on these innovations. The core hypothesis tested is that firms face difficulties in applying knowledge that comes from areas they are not familiar with. Therefore, firms exploit spillovers for improving their products rather than for producing completely new products. Skills, experiences and abilities within a firm are required to assimilate and exploit outside information. Learning from rivals is less costly and timeconsuming if a firm already produces products which embody know-how related to the rivals' knowledge. Furthermore, drastic product innovations often require a rather radical reorganization of production. Only modest changes within the firm are needed to launch incremental product innovations. Thus, using rivals’ knowledge for incremental innovations entails lower adjustment costs. This implies not only lower costs of technological investment but also a lesser degree of employee resistance against innovation and a less severe conflict between the firm's new and its existing activities.

Using an unusually rich data set on a sample of manufacturing establishments in Germany, we estimate the determinants of various types of innovation activities. Incremental product innovations are captured by follow-up products, qualitatively improved products and products with additional functions, while drastic innovation activities are captured by patent applications and the launch of completely new products. Controlling for a variety of other influences, we examine whether spillovers stimulate incremental or drastic innovations. We also investigate if a firm's own R\&D effort or cooperations in $R \& D$ facilitate the use of knowledge spillovers. Multivariate probit estimates show that knowledge spillovers from rivals have a positive impact on incremental innovations. This impact is largely independent 
of participation in $\mathrm{R} \& \mathrm{D}$ cooperations. Spillovers exert no independent influence on drastic innovation activities. The results support the hypothesis that establishments face difficulties in using knowledge that comes from areas they are not familiar with. Establishments exploit spillovers primarily for innovations that are closely related to their existing activities. The results also show that $R \& D$ cooperations to some extent help to overcome the difficulties in using spillovers for drastic innovations. Yet we do not find evidence that the firm's own R\&D effort facilitates the use of spillovers. Quite the contrary, our estimates show that own R\&D effort and the use of outside knowledge are rather substitutive. This provides support for recent theoretical contributions by Jovanovic and MacDonald (1994), Eeckhout and Jovanovic (2002) and Knott (2003). Establishments with high R\&D effort are closer to the frontier of technology and product development. Since they have less to learn from others, outside knowledge is less useful to them. In contrast, establishments with low R\&D effort have to learn a lot from others. Thus, knowledge spillovers from rivals and the information exchange within R\&D cooperations are more valuable to laggard establishments.

Dewar and Dutton (1986) examine in a related study the determinants of incremental and radical process innovations. They do not find a significant association between exposure to external information and either type of process innovation. However, the study is limited to a very small sample of 40 footwear manufacturers in the United States. In contrast, a study by Peters and Becker (1998) shows that knowledge spillovers from competitors have an impact on the introduction of improved products but not on the introduction of completely new products. Our examination differs from this study in several respects. First, Peters and Becker provide no theoretical background to explain their result. The variable for knowledge spillovers is simply a control variable in their paper. Second, Peters and Becker's analysis is restricted to the German automobile industry, while our sample covers establishments from the whole manufacturing sector. Third, our analysis is based on a more detailed differentiation of innovative activities including patenting. Finally, and perhaps most importantly, we 
provide a detailed analysis of the role R\&D plays in the use of knowledge spillovers.

The rest of the paper is organized as follows. Section 2 provides a detailed discussion on the type of innovation that is stimulated by knowledge spillovers. Section 3 describes the data set and discusses variables and the estimation method. Section 4 presents the results of the empirical investigation, while Section 5 concludes.

\section{Hypotheses}

\subsection{Learning and Reorganization of Production}

Learning and the capabilities to learn are at the heart of innovative activities. Strategic management literature stresses that learning is predominantly cumulative and closely related to the firm's previous activities. New knowledge builds upon experience accumulated in earlier periods. As past experience has a strong impact on a firm's future activities, innovations usually take place as a succession of incremental changes. Major shifts and discontinuities are relatively rare. Teece et al. (1994, p. 17) argue that

'opportunities for successful new developments will be 'close in' to previous activities ... This is because learning is a process of trial, feedback, and evaluation. If too many parameters are changed simultaneously, the ability of firms to conduct meaningful natural quasi experiments is attenuated. If many aspects of a firm's learning environment change simultaneously, the ability to ascertain cause-effect relationships is confounded because cognitive structures will not be formed and rates of learning diminish as a result.'

This has a crucial implication for the use of knowledge spillovers. If the firm's learning capabilities depend on its previous experiences, the firm will assimilate and exploit rivals' knowledge closely related to its own products and processes. Learning from rivals is less costly and time-consuming when the firm already produces products which embody knowhow similar to that of their rivals. The most obvious case is that the transferred outside 
information is highly fragmentary and incomplete. Firms with related know-how will face less severe difficulties in filling the gaps than firms with rather unrelated experiences. But even if the rivals' knowledge is completely disclosed, outside information will be less likely to be of use to firms which have no complementary knowledge to comprehend and assimilate it. Therefore, we anticipate that product innovations stimulated by knowledge spillovers from rivals are usually incremental rather than drastic.

The reasoning has strong similarities to Spence's (1981) analysis of interdependent learning curves. Spence assumes an individual firm's unit cost function which is not only decreasing in the firm's own output but also in total industry output. Moreover, he considers the complementarity between firm-specific experience and industry experience. The individual firm's capacity to absorb industry experience is greater if it accumulates its own experience closely related to the know-how of other firms in the industry. An obvious extension is to apply the concept of interdependent learning curves not only to cost reductions but also to product innovations. Accumulated experience from producing similar products enhances a firm's absorptive capacity to use rivals' knowledge for incremental product innovations.

This aspect becomes even more important if one takes into account that learning from competitors does not only refer to the attributes of a new product. As launching new products usually requires a reorganization of production, learning from rivals involves aspects of organizational change. The adopting firm must look for ways to adjust its production process. While incremental product innovations entail only modest changes, completely new products require more radical changes in routines and technologies. Furthermore, a radical reorganization of production may cause higher adjustment costs as it involves severe resistance to change from production and managerial employees (Ichniowski and Shaw, 1995; Milgrom and Roberts, 1995). ${ }^{1}$ Competence-destroying change requires renewed effort and investments on the part of the employees. Moreover, superiors may fear that they will lose 
authority when a radical reorganization takes place. Workers may suspect that they will lose their jobs due to radical technological change. Therefore, learning how to restructure production and implementing organizational change are more difficult in the case of drastic product innovations.

Furthermore, coherence of activities may play an important role in the firm's strategy. ${ }^{2}$ This also applies to its innovative activities. Implementing a completely new product may involve a severe conflict between the firm's new and its old activities. The technology required to produce the drastic product innovation may interfere with the technology required to produce the firm's established products. In that case, a reorganization of production does not only involve high technological investments or a high degree of employee resistance. It may impair the firm's capabilities to pursue its existing activities. Similarly, the marketing strategy to successfully launch the drastic product innovation may interfere with the strategy for selling the firm's other products. Learning ways to achieve coherence is easier if the firm launches an incremental product innovation which is more or less closely related to its existing activities.

In summary, firms will normally use knowledge spillovers from rivals for incremental rather than for drastic product innovations. As firms face difficulties in using knowledge that comes from areas they are not familiar with, they are likely to exploit outside information for improving their products rather than for producing completely new products. Furthermore, incremental innovations entail only a moderate reorganization of production, a lower degree of worker resistance and a less severe conflict between the firm's new and its old activities.

One scenario is that a firm does not simply imitate rivals' products but uses knowledge spillovers for developing its own products. In this case, knowledge spillovers stimulate incremental innovations that are new to both the firm and the market. The second scenario is that spillovers primarily serve the diffusion of new products across firms. In that case, a firm primarily exploits knowledge spillovers to imitate rivals' products and, hence, to launch 
products which are only new to the adopting firm. Our hypothesis suggests that the firm will usually only imitate new products that are closely related to its old products. Taken into account the heterogeneity of adjustment costs among firms, a rival may launch a completely new product which is not imitated by other firms in the market. ${ }^{3}$ For example, new entrants may have relatively low costs of bringing drastic innovations to market while established firms may have prohibitively high adjustment costs preventing them from imitation.

\subsection{The Role of $R \& D$ and Cooperations in $R \& D$}

$\mathrm{R} \& \mathrm{D}$ is an important input in the innovation process. Thus, one may argue that the link between spillovers and product innovations depends on the firm's R\&D activities. There are several reasons why R\&D may play a role in the use of knowledge spillovers.

First, spillovers from rivals might stimulate the firm’s R\&D activities which in turn exert a positive impact on product innovations launched by the firm. If spillovers are primarily inputs in the firm's $R \& D$ and no direct inputs in its innovation output, the association between spillovers and product innovations would be driven by spurred R\&D activities. Yet if the firm's learning capacity rather depends on the relatedness of its past and present activities to those of its rivals, there will be a direct association between the use of knowledge spillovers and the launch of incremental product innovations. ${ }^{4}$ The association between spillovers and incremental innovations will be at least partially independent of the firm's R\&D activities. In the extreme case, knowledge spillovers from rivals are important for the firm's innovations even if they are no input in its R\&D and hence do not influence R\&D expenditures (Levin, 1988). To test this, we run regressions without and with control variables for R\&D. In case the link between spillovers and innovations is basically driven by spurred R\&D activities, the inclusion of $R \& D$ variables should cause the coefficients on the spillover variable to attenuate. By contrast, if the link between spillovers and innovations is direct and independent of the firm's R\&D activities, the inclusion of those controls should not cause a substantial 
attenuation of the coefficients on the spillover variable.

However if a direct link exists between spillovers and innovations, the strength of this link may depend on the firm's R\&D activities. This brings us to the second possible role of R\&D. In case $R \& D$ enhances the firm's absorptive capacities, a positive interaction of $R \& D$ and the use of knowledge spillovers can be expected (Cohen and Levinthal, 1989). This might apply to both incremental and drastic product innovations. The impact of spillovers on incremental innovations will be more pronounced if a firm's own R\&D strengthens the absorptive capacities created by activities that are related to those of the rivals. Insofar $R \& D$ enhances absorptive capacities to a substantial extent, firms with $R \& D$ might even use spillovers to launch drastic product innovations.

Yet recent theoretical contributions by Jovanovic and MacDonald (1994), Eeckhout and Jovanovic (2002) and Knott (2003) highlight a diametrically opposed role played by a firm’s own R\&D in the use of outside information. This role implies a negative interaction effect between $R \& D$ and the use of knowledge spillovers. The basic hypothesis is that knowledge spillovers from rivals are less valuable to firms which are at the frontier of technology and product development. The more a firm knows the less it has to learn from other firms. In contrast, firms which are far below the frontier of technology and product development have to learn a lot from other firms, specifically from those that are closer to the frontier. Therefore, knowledge spillovers from rivals are more valuable to laggard firms. A study by Knott, Wu and Posen (2004) provides empirical support for this hypothesis. Using data from firms in the US banking sector, their frontier analysis confirms that spillovers are asymmetric. Firms with a larger degree of technical inefficiency benefit more from spillovers. The theoretical implication of the hypothesis is a specialization of firms (Jovanovic and MacDonald, 1994; Eeckhout and Jovanovic, 2002). ${ }^{5}$ Some firms take a leadership role by investing in $\mathrm{R} \& \mathrm{D}$ and producing new knowledge. As they are operating at the frontier of technology and product development, rivals' knowledge is less useful for their innovation 
activities. Other firms take a follower role. Instead of extensively investing in R\&D, they specialize in learning from technological leaders. Leaders and followers can coexist if informational barriers imply that the diffusion of knowledge is incomplete. As discussed, firms will usually use knowledge spillovers from rivals for incremental rather than for drastic innovations.

Furthermore, it is important to consider that firms undertaking R\&D are often involved in $R \& D$ cooperations with other firms and institutions. To avoid confounding the influence of the firm's own R\&D expenditures and the influence of a participation in R\&D cooperations, it is crucial to distinguish between both aspects in the theoretical and empirical analysis. It may be that $R \& D$ cooperations rather than the firm's own $R \& D$ expenditures play a supportive role in the use of knowledge spillovers. Branstetter and Sakakibara (1998) highlight this role of $R \& D$ cooperations. They show that participation in $R \& D$ consortia has a positive impact on the research productivity of Japanese firms. Part of this impact appears to arise from increased knowledge spillovers within the consortia. This finding supports the notion that $R \& D$ cooperations serve as a vehicle to improve voluntary or involuntary information flows and to get access to outside information. This may not only apply to cooperations with rivals. Even cooperations with suppliers, customers, universities or other research organizations can provide an improved access to rivals' knowledge. This may also involve information about ways to reorganize production and to ensure coherence of the firm's new and old activities. Therefore if R\&D cooperations substantially help to improve learning, participating firms may use rivals’ knowledge even for drastic innovations.

\section{Data, Variables and Method}

\subsection{Data Set}

The empirical investigation is based on the Hanover Panel, a four-wave panel with data from manufacturing establishments in the federal state of Lower Saxony. ${ }^{6}$ The population consists 
of all manufacturing establishments with five or more employees. The sample is stratified according to firm size and industry. Interviews were conducted by Infratest Sozialforschung, a professional survey and opinion research institute. The data were collected on the basis of a questionnaire in personal interviews with the owner, top manager or head of the personnel department. In the first wave of interviews (1994), which was financed by the Volkswagen Foundation, 51 percent of the establishments in the sample agreed to participate. In spite of this non-response rate the difference between the planned and realized stratification is so small that the data are representative of the manufacturing establishments in Lower Saxony in 1994 and in the subsequent waves. The number of firms taking part in the panel study declined from 1025 (1994) to 849 (1995), 721 (1996) and 709 (1997). ${ }^{7}$

Apart from basic information on the establishment, a nucleus of themes was addressed annually. Additional topics were sampled in successive waves. Several questions needed for the construction of critical variables needed for this inquiry were only addressed to interviewees in the second and in the fourth wave. The estimates are based on pooled data for the years 1995 and 1997. Furthermore, the analysis is restricted to establishments generally developing new products. Only those establishments answered the question regarding the use of knowledge spillovers.

Askildsen, Jirjahn and Smith (2006) have also used the data to study the determinants of environmental investments and innovations. Our paper differs in several respects from this earlier work. Though Askildsen, Jirjahn and Smith distinguish between several environmentally-friendly process innovations, they do not differentiate between incremental and drastic product innovations. In our study, we distinguish between various types of incremental and drastic product innovations. Furthermore, Askildsen, Jirjahn and Smith do not investigate the impact of spillovers on innovations. Investigating this impact is at the heart of our examination. 


\subsection{Variables for Incremental and Drastic Product Innovations}

Table 1 presents the definitions of all variables used. The descriptive statistics are shown for the pooled sample of establishments. The data set is unique in that it offers a range of information about types of product innovations launched by the establishments in the respective year. Incremental product innovations are captured by dummy variables for the launch of follow-up products, FOLLPROD, products with improved quality, QUALPROD, and products with additional functions, FUNCPROD. In the pooled sample, there are about $33 \%$ of observations with follow-up products, $34 \%$ with qualitatively improved products, and 20\% which launched products with additional functions.

Drastic product innovations are captured by a dummy variable $N E W P R O D$ for the launch of completely new products. Finally, PATENT is a dummy variable equal to 1 if the establishment filed patents in the respective year. Investigating the determinants of patent applications helps to sharpen the interpretation of our results. As German law makes high demands on the novelty of patented products, this variable is closely related to drastic innovative activities. In the pooled sample, there are about $22 \%$ of observations with the introduction of completely new products, and $16 \%$ with patent applications.

\subsection{Variables for Spillovers and $R \& D$}

The data set is also unique in that it provides a rich set of explanatory variables. This affords the opportunity to include not only indicators for establishment size, $R \& D$, competition and market strategy but also variables for human resource management, industrial relations, technology and the structure of the workforce.

Most importantly, the survey provides information on knowledge spillovers from rivals. The dummy variable RIVALIDEA is equal to 1 , if the establishment observes competitors to get ideas for product development, and 0 otherwise. $45 \%$ of the establishments reported that they get innovative ideas by observing the actions of their competitors. Based on our theoretical 
considerations, we anticipate that spillovers from competitors will exert a positive impact on the variables for incremental product innovations but not on the variables for drastic product innovations.

The data provide several alternative variables for $R \& D$. RESEARCH is a dummy variable equal to 1 if the establishment engages in $R \& D$, and 0 otherwise. Note that all establishments in the sample reported generally developing new products. But only $50 \%$ of these establishments engage in R\&D. Innovative activities are often undertaken by firms even when they do not have institutionalized R\&D (Kleinknecht, 1987; Brouwer and Kleinknecht, 1997). Yet, to the extent R\&D reflects more systematic innovative activities and higher investments in those activities, we anticipate that $R \& D$ is an important input in the innovation process which exerts a positive impact on the innovation output.

Alternatively, we use the proportion of employees involved in $\mathrm{R} \& \mathrm{D}, \mathrm{RESEARCHSTAFF}$, and a dummy, RESEARCHCOOP, equal to 1 if the establishment has R\&D cooperations with other firms and institutions. This allows us to distinguish between the role of the establishment's own research effort and the role of cooperations. Note that about $44 \%$ of all establishments are involved in R\&D cooperations. Only 6\% undertake R\&D without a cooperation.

To test if the association between $R \& D$ and innovations is direct or indirect, we run regressions with and without our $\mathrm{R} \& \mathrm{D}$ measures. If the association between spillovers and product innovations is driven by spurred $R \& D$ activities, the inclusion of $R \& D$ variables should cause the coefficients on the spillover variable to attenuate. If the link is direct and the establishment's absorptive capacities basically depend on the relatedness of its activities to those of its rivals, there should be no substantial attenuation. Finally, we test if there are interaction effects between our key variables by including RESEARCHSTAFF RIVALIDEA, RESEARCHCOOP*RIVALIDEA and RESEARCHSTAFF*RESEARCHCOOP. 


\subsection{Control Variables}

Empirical and theoretical analyses indicate that managers play a very important role in the firm's innovation activities. Harhoff (1999) finds that innovative activities of firms are influenced by the education of the firms' managers. Czarnitzki and Kraft (2004) show that innovative activities are influenced by the separation of ownership and control. To control for managers supporting innovation activities, we include a dummy variable, MANAGERIDEA, equal to 1 if ideas from executive managers or owners of the establishment play an important role in developing new products.

Several variables capture the market strategy of the establishment. MARKETINGIDEA is a dummy variable equal to 1 if ideas from the establishment's marketing department play an important role in developing products. CUSTOMERIDEA is a dummy variable equal to 1 if ideas from customers play an important role in developing products. Both variables reflect an active strategy of looking for new market opportunities via systematic market research or direct communication with customers. Responding to changing customer demands with innovative activities and entering markets with new products is at the heart of this strategy.

Furthermore, we include a variable for the establishment's relationship to its customers. CUSTOMERSPECIALIZE is a dummy variable equal to 1 if the establishment concentrates on a particular customer group. On the one hand, an establishment may have an incentive to develop new products that meet the specific needs of this customer group. On the other hand, the incentives to engage in innovative activities may be reduced if the establishment concentrates on customers with substantial buyer market power (Peters, 2000).

SALESMAINPRODUCT is a variable for the percentage of sales attributed to the main product group. This variable is an inverse measure of a multiproduct establishment. A high degree of product diversity enables the establishment to diversify risk. Nelson (1959) argues that this enhances its willingness to undertake innovative activities. Therefore, we anticipate a negative association between the percentage of sales attributed to the main product group and the 
establishment's innovations.

Two variables capture competition among firms in the product market. PRESSURE is a dummy variable equal to 1 if managers answered that the pressure from competitors is very high, and 0 otherwise. EXPORT is the percentage of the establishment's sales generated by exports. A widespread view is that product market competition provides incentives to improve efficiency within firms. This may also include increased innovativeness. However, theoretical analyses show that competition may increase or decrease the efficiency of firms. On the one hand, competition may imply a threat of liquidation which induces efficiencyenhancing investments in order to reduce the probability of bankruptcy (Schmidt, 1997). On the other hand, product market competition reduces the incentives to engage in innovative activities in case a shrinkage effect dominates (Martin, 1993). While a greater number of competitors increases industry output, the sales potential of each individual firm decreases. Similarly, Boone (2000) argues that product market competition involves a discouragement effect when a firm faces superior competitors. Moreover, increased competition may involve an increased probability that a firm's own innovations are imitated by other firms. Innovation incentives decrease if the firm is less likely to be able to appropriate the returns from its innovative activities.

The survey provides information related to the flexibility of the establishments on implementing new products. The variable TEAM indicates that at least $10 \%$ of blue-collar workers in the establishment are organized in production teams with expanded autonomy and multiple responsibilities. An organization of work characterized by reduced specialization, multi-tasking and horizontal communication is a crucial element of the concept of flexible production (Milgrom and Roberts, 1995). The opportunity to use labor in a more versatile way may facilitate innovation activities (Laursen and Foss, 2003).

Profit sharing for employees, PROFITSHARING, is also taken into account. Profit sharing has been thought to provide incentives for helping on the job and to induce cooperation both 
among employees and between management and employees (FitzRoy and Kraft, 1987). Such cooperative relations may be needed whenever innovative changes are implemented. Further, profit sharing provides incentives for multi-tasking (Jirjahn, 2000). These incentives are crucial if a change of products requires the switch from one task to another.

Employees having a better understanding of the production process may be important for the implementation of new products. Nickell and Nicolitsas (2000) provide evidence for an association between the availability of human capital on the one hand and the rate of accumulation of knowledge capital on the other. We capture the employees' initial human capital by two variables. The proportion of blue-collar workers, BLUECOLLAR, is generally recognized as a proxy for a less qualified workforce (Berman, Bound and Machin, 1998). In contrast, the proportion of university and college graduates, UNIVERSITY, is a measure of highly qualified white-collar employees.

TRAINING is a dummy variable equal to 1 if the establishment finances continuous training for the employees. New products may involve new qualification requirements. Thus, product innovations may contribute to the obsolescence of the employees' initial qualifications. Continuous training enables employees to cope with new qualification requirements (Gerlach and Jirjahn, 2001). Therefore, further training provided by the employer complements the establishment's innovation activities.

Industrial relations may also play a role in the firm's innovativeness. The link between unionization and innovations has been extensively examined with Anglo-Saxon data (Menezes-Filho, Ulph and Van Reenen, 1998). However, German industrial relations are characterized by a dual structure of employee representation with both works councils and unions (Hübler and Jirjahn, 2003). Works councils provide a highly developed mechanism for establishment-level participation, while collective bargaining agreements are usually negotiated between unions and employers’ associations on an industrial level.

Works councils are elected by the workforce of establishments with five or more 
employees, although their creation depends on the initiative of the establishment's employees. Hence, they are not present in all eligible establishments. Works councils may play a role in building trustful industrial relations within establishments (Freeman and Lazear, 1995; Askildsen, Jirjahn and Smith, 2006). Employees may refuse cooperation when an employer cannot credibly commit to take their interests into account. If information about potentially performance-enhancing innovations is in the hand of the employees, they may not wish to reveal it for fear that the employer might use the information to their disadvantage. Providing works councils with codetermination rights is one possible way to protect the interests of the workforce and to cooperatively realize mutual gains for the employees and the owners of the firm. If a council improves the information flow within the establishment, it can be expected that this will provide management with ideas about incremental improvements of products (Smith, 1994). In the regressions, the presence of a works councils, WORKSCOUNCIL, is taken into account.

We also include an indicator COLLECTBARGAIN of whether the establishment is covered by a collective agreement. Given the degree of centralization of collective bargaining in Germany, it is not likely that collective bargaining can take a similar role for innovations like establishment codetermination. Centralized collective bargaining rather might impose restrictions on the establishments' flexibility. ${ }^{8}$ This would imply a negative association between the coverage by a collective agreement and innovations.

Economies of scale are captured by SIZE, the number of employees in the establishment. In order to take into account a non-linear impact of firm size, its square, SIZESQUARED, is also included. An additional measure of economies of scale is a dummy, SHIFTWORK, equal to 1, if the establishment uses shift work.

Further, a variable for technological opportunities is included. TECHNEW is a dummy variable equal to 1 if the establishment uses a state-of-the-art production technology. The proportion of women, WOMEN, is also included. Since women are thought to work in more 
service-oriented industrial groups, this variable may reflect modes of production that are not typical for the traditional manufacturing industry. If these modes of production are characterized by a greater innovativeness, there will be a positive association between the share of women and product innovations. Finally, to control for varying technologies across industries, variables for 12 broadly defined industrial groups in the manufacturing sector are included.

\subsection{Estimation Method}

As our five dependent innovation variables are binary, we use a multivariate probit model. ${ }^{9}$ This model is a generalization of the bivariate probit model (see Greene, 2003). In principle, the method is similar to the SUR model. The basic probit model is extended by allowing for correlated disturbances in a similar way as it is done by the seemingly unrelated regression framework. However, the estimation procedure is much more complicated. Let $y_{i m}$ denote the decision of establishment $i$ to launch innovation type $m(m=1, \ldots, 5)$. The decision is defined by

$$
y_{\text {im }}=\left\{\begin{array}{l}
1, \text { if } y_{\text {im }}^{*}>0 \\
0, \text { otherwise }
\end{array}\right.
$$

with the latent model

$$
y_{i m}^{*}=\boldsymbol{\beta}_{m}^{\prime} \boldsymbol{x}_{i m}+\varepsilon_{i m}
$$

where $\boldsymbol{x}_{i m}$ is the vector of establishment characteristics, $\boldsymbol{\beta}_{m}$ the vector of coefficients and $\varepsilon_{i m}$ the error term. The error terms of the innovation decisions are assumed to be jointly five variate normally distributed with zero mean. Given that the variances of the error terms are equal to 1 , the variance-covariance matrix is

$$
\Sigma=\left(\begin{array}{ccc}
1 & \cdots & \sigma_{15} \\
\vdots & \ddots & \vdots \\
\sigma_{51} & \cdots & 1
\end{array}\right)
$$

where the subindices indicate the innovation decisions to which the covariance refers. If the 
error terms of the innovation decisions are not correlated, the five innovation equations could be estimated separately. In our study the equations are estimated simultaneously using a multivariate probit model. This gives the opportunity to test whether or not the correlations are actually different from zero. The log-likelihood function, $\ln L$, for the multivariate probit model is

$$
\ln L=\sum_{i=1}^{n} \ln \Phi_{5}\left(\boldsymbol{\mu}_{i}, \Sigma^{*}\right)
$$

where $\Phi_{5}\left(\boldsymbol{\mu}_{i}, \Sigma^{*}\right)$ is a standard five variate normal cdf with

$$
\boldsymbol{\mu}_{i}=\left(q_{i 1} \boldsymbol{\beta}_{1}^{\prime} \boldsymbol{x}_{i 1}, \ldots, q_{i 5} \boldsymbol{\beta}_{5}^{\prime} \boldsymbol{x}_{i 5}\right)
$$

and $q_{i m}=2 y_{i m}-1$. Therefore, $q_{i m}=1$ if $y_{i m}=1$ and $q_{i m}=-1$ if $y_{i m}=0$. The symmetric matrix $\Sigma *$ is given by

$$
\Sigma^{*}=\left(\begin{array}{ccc}
1 & \cdots & q_{i 1} q_{i 5} \sigma_{15} \\
\vdots & \ddots & \vdots \\
q_{i 5} q_{i 1} \sigma_{51} & \cdots & 1
\end{array}\right)
$$

The practical obstacle in estimating a multivariate probit model is the evaluation of the highorder multivariate normal integrals. Therefore, the multivariate standard normal distribution is evaluated using a simulation method based on the Geweke-Hajivasiliou-Keane simulator. This method exploits the fact that a multivariate normal distribution function can be expressed as the product of sequentially conditioned univariate normal distribution functions, which can be evaluated more easily. The possible combinations of the outcomes ( $y_{i m}=1$ or $y_{i m}=0$ ) are represented by their probabilities, and this is exemplified by the case that all endogenous variables are equal to one:

$$
\operatorname{Pr}\left(y_{i 1}=\ldots=y_{i 5}=1\right)=\operatorname{Pr}\left(\varepsilon_{i 1} \leq \boldsymbol{\beta}_{1}^{\prime} \boldsymbol{x}_{i 1}, \varepsilon_{i 2} \leq \boldsymbol{\beta}_{2}^{\prime} \boldsymbol{x}_{i 2}, \varepsilon_{i 3} \leq \boldsymbol{\beta}_{3}^{\prime} \boldsymbol{x}_{i 3}, \varepsilon_{i 4} \leq \boldsymbol{\beta}_{4}^{\prime} \boldsymbol{x}_{i 4}, \varepsilon_{i 5} \leq \boldsymbol{\beta}_{5}^{\prime} \boldsymbol{x}_{i 5}\right)
$$

Given that an analytical solution is intractable, the probability is approximated through simulation. The idea of the GHK simulator is to deal with the error terms sequentially and to solve the difficulty by recursive simulation in order to break a complicated situation into 
relatively simple components. The probability $\operatorname{Pr}\left(y_{i 1}=\ldots=y_{i 5}=1\right)$ can be written as the product of one unconditional and four conditional probabilities according to:

$$
\begin{gathered}
\operatorname{Pr}\left(y_{i 1}=\ldots=y_{i 5}=1\right)= \\
\operatorname{Pr}\left(\varepsilon_{i 1} \leq \boldsymbol{\beta}_{1}^{\prime} \boldsymbol{x}_{i 1}\right) * \operatorname{Pr}\left(\varepsilon_{i 2} \leq \boldsymbol{\beta}_{2}^{\prime} \boldsymbol{x}_{i 2} \mid \varepsilon_{i 1} \leq \boldsymbol{\beta}_{1}^{\prime} \boldsymbol{x}_{i 1}\right) * \operatorname{Pr}\left(\varepsilon_{i 3} \leq \boldsymbol{\beta}_{3}^{\prime} \boldsymbol{x}_{i 3} \mid \varepsilon_{i 2} \leq \boldsymbol{\beta}_{2}^{\prime} \boldsymbol{x}_{i 2}, \varepsilon_{i 1} \leq \boldsymbol{\beta}_{1}^{\prime} \boldsymbol{x}_{i 1}\right) \\
* \operatorname{Pr}\left(\varepsilon_{i 4} \leq \boldsymbol{\beta}_{4}^{\prime} \boldsymbol{x}_{i 4} \mid \varepsilon_{i 3} \leq \boldsymbol{\beta}_{3}^{\prime} \boldsymbol{x}_{i 3}, \varepsilon_{i 2} \leq \boldsymbol{\beta}_{2}^{\prime} \boldsymbol{x}_{i 2}, \varepsilon_{i 1} \leq \boldsymbol{\beta}_{1}^{\prime} \boldsymbol{x}_{i 1}\right) \\
* \operatorname{Pr}\left(\varepsilon_{i 5} \leq \boldsymbol{\beta}_{5}^{\prime} \boldsymbol{x}_{i 5} \mid \varepsilon_{i 4} \leq \boldsymbol{\beta}_{4}^{\prime} \boldsymbol{x}_{i 4}, \varepsilon_{i 3} \leq \boldsymbol{\beta}_{3}^{\prime} \boldsymbol{x}_{i 3}, \varepsilon_{i 2} \leq \boldsymbol{\beta}_{2}^{\prime} \boldsymbol{x}_{i 2}, \varepsilon_{i 1} \leq \boldsymbol{\beta}_{1}^{\prime} \boldsymbol{x}_{i 1}\right)
\end{gathered}
$$

The general methodology is a Cholesky decomposition of the covariance matrix for the errors

$$
\mathrm{E}\left(\varepsilon \varepsilon^{\prime}\right)=\Gamma \Gamma^{\prime}
$$

where $\boldsymbol{\Gamma}$ is the lower triangular Cholesky matrix with the elements $\gamma_{m j}$. In the first place the unconditional probability $\operatorname{Pr}\left(\varepsilon_{i 1} \leq \boldsymbol{\beta}_{1}^{\prime} \boldsymbol{x}_{i 1}\right)$ is computed by drawing the random observations $e$ from the standard normal distribution $e_{1} \sim N(0,1)$ subject to the constraint $e_{1} \leq \boldsymbol{\beta}_{1}{ }^{\prime} \boldsymbol{X}_{1} / \gamma_{11}$. Based on this drawing the probability $Q_{1}=\Phi\left(\boldsymbol{\beta}_{1}{ }^{\prime} \boldsymbol{X}_{1} / \gamma_{11}\right)$ is calculated. In the next step recursively the random variables $e_{m}$ are drawn from $N(0,1)$ subject to the condition (the truncation points) $e_{m} \leq\left(\boldsymbol{\beta}_{m}{ }^{\prime} \boldsymbol{X}_{m}-\sum_{j=1}^{m-1} \gamma_{m j} e_{j}\right) / \gamma_{m m}$. Next the conditional probability $Q_{m}=\Phi\left[\left(\boldsymbol{\beta}_{m}{ }^{\prime} \boldsymbol{X}_{m}-\sum_{j=1}^{m-1} \gamma_{m j} e_{j}\right) / \gamma_{m m}\right], m=2,3,4,5$ is computed and the product $\prod_{m=1}^{5} Q_{m}$ is calculated. The advantage of these calculations is the fact that the $e$ 's are independent normal distributed random variables and hence the probability which we want to evaluate can equivalently be expressed as a product of independent univariate cumulative density functions. This procedure is repeated another $S$ - 1 times and the average is the simulation of the probability in question:

$$
\begin{gathered}
\operatorname{Pr}=\frac{1}{S} \sum_{s=1}^{S} \prod_{m=1}^{5} Q_{m} \\
=\frac{1}{S} \sum_{s=1}^{S}\left\{\Phi\left(\boldsymbol{\beta}_{1}{ }^{\prime} \boldsymbol{X}_{1} / \gamma_{11}\right) * \Phi\left[\left(\boldsymbol{\beta}_{2}{ }^{\prime} \boldsymbol{X}_{2}-\gamma_{21} e_{1}\right) / \gamma_{22}\right] * \Phi\left[\left(\boldsymbol{\beta}_{3}{ }^{\prime} \boldsymbol{X}_{3}-\gamma_{32} e_{2}-\gamma_{31} e_{1}\right) / \gamma_{33}\right]\right. \\
\left.* \Phi\left[\left(\boldsymbol{\beta}_{4}{ }^{\prime} \boldsymbol{X}_{4}-\gamma_{43} e_{3}-\gamma_{42} e_{2}-\gamma_{41} e_{1}\right) / \gamma_{44}\right] * \Phi\left[\left(\boldsymbol{\beta}_{5}{ }^{\prime} \boldsymbol{X}_{5}-\gamma_{54} e_{4}-\gamma_{53} e_{3}-\gamma_{52} e_{2}-\gamma_{51} e_{1}\right) / \gamma_{55}\right]\right\}
\end{gathered}
$$


All other probabilities can be computed similarly. After inserting them into the likelihood function, standard maximization procedures can be used in order to estimate the parameters of interest.

\section{Empirical Results}

\subsection{Initial Regression Results}

Our initial estimates without controls for $R \& D$ and cooperations in $R \& D$ are shown in Table 2. With only one exception, the estimated correlation coefficients between the error terms are highly significant. This confirms that unobserved random determinants influence the several types of innovation in the same direction.

Many of the explanatory variables are statistically significant and take coefficients of the expected sign. A supportive managerial environment has a positive influence on both incremental and drastic innovations. Ideas from executive managers or owners increase the probability of qualitatively improved products, products with additional functions and completely new products.

The skills of the workforce play a positive role in innovation activities. Establishments financing further training for their employees are more likely to file patents and to launch qualitatively improved products, products with additional functions and completely new products. The probability of patent applications increases with the proportion of university and college graduates. The share of blue-collar workers as an inverse measure of skills decreases the probability of both follow-up products and patent applications. The share of women is positively associated with qualitatively improved products and completely new products. Although we have controlled for line of business, the positive association between the gender composition of the workforce and innovations may reflect the sorting of women into more service-oriented establishments within the manufacturing sector.

Profit sharing is a positive determinant of patent applications. Establishments with self- 
managed production teams are more likely to launch products with additional functions and completely new products. This positive association between teams and innovations supports the notion that flexible production facilitates a change of products. Yet teams are negatively associated with patent applications. An explanation may be that flexible production aims at speedy responses to changing market demands. As it usually takes several years till a patent is granted, establishments with flexible production may prefer incremental or drastic product innovations they can directly launch without patent protection.

Turning to the variables for industrial relations, the estimates show that collective bargaining and establishment-level codetermination play different roles. Coverage by a collective bargaining agreement is negatively associated with both incremental and drastic innovation activities. This may be explained by the restrictions centralized collective bargaining imposes on the establishments' flexibility. The presence of a works council has a positive influence on two types of incremental product innovation but no influence on our measures of drastic innovation activities. The positive influence of works councils supports the notion that establishment-level codetermination facilitates innovations by building trustful employer-employee relationships and improving the information flow within the establishment. This particularly appears to facilitate incremental innovations.

The variables for the scale of production are positive determinants of innovation activities. Establishment size increases the probability of follow-up products, qualitatively improved products and products with additional functions, but at a decreasing rate. There is also a positive link between the size of the establishment and patent applications. Shift work is a positive determinant of follow-up products, completely new products and patent applications.

Establishments operating under strong competitive pressure are less likely to launch both qualitatively improved and completely new products. Competitive pressure may imply a decreased sales potential and, hence, a shrinkage effect decreasing the incentives to undertake innovations. In contrast, the percentage of sales generated by exports exerts a positive 
influence on qualitatively improved products, products with additional functions and patent applications. A high export share may reflect a high international sales potential, stimulating innovative activities.

Specialization to one main product group tends to decrease innovation activities. The percentage of sales attributed to the main product group has a negative influence on follow-up products and completely new products. A low degree of product diversity and, hence, a low degree of risk diversification may reduce the incentive to innovate. Further, establishments are less likely to launch qualitatively improved products and to file patents if they specialize for a particular customer group. This market strategy may increase the dependence on customers with substantial buyer market power and, hence, result in decreased innovation incentives.

An active strategy of looking for new market opportunities via systematic market research or direct communication with customers has a positive influence on incremental product innovations but no influence on drastic innovation activities. Ideas from the establishment's marketing department increase the probability of follow-up products, qualitatively improved products and products with additional functions. Ideas from customers increase the probability of follow-up products and qualitatively improved products. The estimates show no statistically significant influence of active market research and communication with customers on patent applications or the launch of completely new products. This is a first hint that establishments use outside information for incremental rather than for drastic innovations.

Of primary importance, knowledge spillovers from competitors have an influence on incremental product innovations but no influence on drastic innovations. The estimates show a statistically significant association between the use of knowledge spillovers and two types of incremental innovations, namely follow-up products and qualitatively improved products. In contrast, the estimates show no significant association between the use of knowledge spillovers and our variables for drastic innovation activities. Altogether, these results provide 
evidence for our basic hypothesis. Establishments use spillovers from rivals primarily for incremental product innovations.

\subsection{The Influence of $R \& D$}

The estimates shown in Table 2 do not control for the establishments' research activities. To test if the pattern of results changes, we take a further step and expand the specification by including variables for R\&D. In Table 3, we include a simple dummy variable for $R \& D$. We only report the coefficients on the R\&D dummy and on the spillover variable. All of the other control variables listed in Table 2 are included in the regression but are suppressed to save space. The R\&D variable performs strongly. It has a statistically significant influence on all five innovation measures. Importantly, the inclusion of this variable does not change the role of knowledge spillovers from rivals.

The simple R\&D variable may confound the influence of the establishment's own R\&D effort and the influence of participating in R\&D cooperations. To distinguish between both influences, we replace the $R \& D$ dummy with the proportion of employees involved in $R \& D$ and a dummy variable for $\mathrm{R} \& \mathrm{D}$ cooperations. The results are shown in Table 4 . The proportion of employees involved in R\&D has only a significant influence on the introduction of completely new products. The participation in R\&D cooperations is a statistically significant determinant of all five innovation measures. This suggests that R\&D cooperations indeed provide opportunities for a very intensive and systematic exchange of information. However, even the inclusion of the two alternative $R \& D$ measures does not alter the earlier pattern of results. Knowledge spillovers from rivals have a positive influence on incremental innovations but no influence on drastic innovations.

\subsection{Interaction Effects}

The pattern of influences may partially remain obscured until interaction effects between our key variables have been considered. Taking the final step, we additionally include three 
interaction variables, namely spillovers interacted with $R \& D$ cooperations, spillovers interacted with the share of $R \& D$ employees, and $R \& D$ cooperations interacted with the share of R\&D employees. ${ }^{10}$ In Table 5a, we use the same specification for the different innovation types by including all three interaction variables in each innovation equation. In Table 5b, we remove insignificant interaction variables (with a T-statistic smaller than one) from some innovation equations. While it improves the statistical significance of individual coefficients, this sensitivity test basically confirms the results of Table 5a.

Indeed, the final estimates show that the influences of a firm's own R\&D effort and R\&D cooperations with others can only be disentangled by including the interaction variables. The share of employees involved in R\&D now emerges as a statistically significant determinant of four types of innovation. It not only influences the introduction of completely new products but also patent applications (in Table 5b) and the launch of products with improved quality and additional functions. Cooperation in R\&D remains a statistically significant determinant of four types of innovation.

The estimates reveal a negative interaction effect of the establishment's R\&D staff and its participation in $R \& D$ cooperations on all three types of incremental innovation. The negative interaction effect implies that the positive influence of $R \& D$ cooperations is stronger if the establishment has a smaller share of research employees. ${ }^{11}$ This finding provides support for the hypothesis that own R\&D effort and the use of outside information are rather substitutes. Establishments with high R\&D effort are closer to the frontier of product development. Since they have less to learn from others, information sharing within the R\&D cooperation is less useful, particularly for their incremental innovation activities. In contrast, the improved information exchange within a cooperative $R \& D$ arrangement is more valuable to establishments with low R\&D effort. Those establishments are likely to be far away from the frontier of product development. Hence, they have to learn a lot from others.

Turning to our explanatory variable of primary interest, knowledge spillovers continue to 
be no significant determinant of patent applications. The finding supports our hypothesis that firms face difficulties in using rivals' knowledge for drastic innovation activities. The interactions of spillovers with $R \& D$ cooperations and with the share of $R \& D$ employees are also statistically insignificant. This suggests that neither own R\&D effort nor the improved information flow within cooperations can help to overcome the difficulties in exploiting rivals’ knowledge for their own patent activities.

There also continues to be no statistically significant association between the spillover variable and the launch of completely new products. The finding provides further support for the hypothesis that firms face difficulties in using knowledge spillovers for drastic innovations. However, the estimates show a significantly positive interaction effect of spillovers and R\&D cooperations on the launch of completely new products. At least for some types of drastic innovation activities, it appears that R\&D cooperations help to overcome the difficulties in using rivals' knowledge. This may involve products new to the adopting firm but not entirely new to the market. Own R\&D effort does not facilitate the use of knowledge spillovers. Quite the contrary, the interaction of spillovers and the establishment's R\&D staff emerges as a significantly negative determinant of launching completely new products. This supports the notion that R\&D effort and the use of rivals’ knowledge are substitutes.

Turning to the variables for incremental innovations, the positive association between the spillover variable and the launch of follow-up products continues to be statistically significant. The interactions of knowledge spillovers with the share of R\&D employees and with R\&D cooperations are insignificant. Thus, using rivals' knowledge for follow-up products is independent of the establishment's R\&D activities. Altogether, the results on follow-up products support our basic hypothesis. It is easier for firms to use rivals' knowledge for incremental innovations closely related to the establishment's experiences and activities. Obviously, related activities enhance the establishment's absorptive capacity independently of its own R\&D effort or R\&D cooperations with others. 
We obtain a very similar conclusion regarding products with additional functions. In our final estimates, knowledge spillovers from rivals emerge as a significantly positive determinant of launching products with additional functions. There is no statistically significant interaction between knowledge spillovers and R\&D cooperations. This provides further support for our basic hypothesis. Establishments particularly use knowledge spillovers for innovative activities in areas they are familiar with. Again, this holds independently of R\&D cooperations. Moreover, the results on products with additional functions confirm that own $R \& D$ effort does not facilitate the use of spillovers. Quite the contrary, there is a significantly negative interaction effect of knowledge spillovers and R\&D cooperations on this type of incremental innovation. This suggests a substitutive relationship between own R\&D effort and the use of rivals' knowledge. Spillovers are more valuable to laggard firms which are far below the frontier of product development, whereas firms operating at the frontier of product development have less to learn from others.

While the estimates on follow-up products and products with additional functions show no significant interaction between $R \& D$ cooperations and spillovers, the interaction of $R \& D$ cooperations and spillovers turns out to be a significantly positive determinant of launching qualitatively improved products. This indicates that R\&D cooperations in some instances also facilitate using spillovers for incremental innovative activities. Yet taken together, the results on our three measures of incremental innovation suggest that using spillovers for incremental innovation activities is to a substantial degree independent of R\&D cooperations. Finally, the estimates show no significant interaction effect of spillovers and own R\&D effort on the launch of qualitatively improved products. Thus, the estimates on qualitatively improved products also provide no evidence that a firm's own R\&D effort facilitates the use of knowledge spillovers.

To summarize, even when controlling for possible interaction effects between our key variables, the estimates support our core hypothesis. Establishments face difficulties in using 
knowledge that comes from areas they are not familiar with. Therefore, establishments use spillovers for incremental rather than for drastic product innovations. The estimates on patent applications and completely new products show no independent influence of knowledge spillovers. An interaction of spillovers with R\&D cooperations emerges as a significantly positive determinant of completely new products whereas it is no significant determinant of patent applications. $\mathrm{R} \& \mathrm{D}$ cooperations facilitate using spillovers for some but not for all drastic innovations. Yet, without R\&D cooperations establishments do not appear to be able to exploit spillovers for drastic innovation activities. These results can be contrasted with the estimates on our three measures of incremental innovation. While the interaction of spillovers and R\&D cooperations emerges as a significant determinant of qualitatively improved products, the positive influence of spillovers on follow-up products and products with additional functions is independent of a cooperation in R\&D. Related experiences and activities enable establishments to use rivals' knowledge for incremental product innovations. Two of three types of incremental innovation provide evidence that this does not depend on R\&D cooperations.

Furthermore, our results support recent theoretical contributions by Jovanovic and MacDonald (1994), Eeckhout and Jovanovic (2002) and Knott (2003). These contributions hypothesize that own R\&D effort and the use of outside information are substitutive. Research-intensive firms operating at the frontier of product development have less to learn from other firms. In contrast, less research-intensive firms, that are far below the frontier, have a lot to learn from others. The estimates show a negative interaction of the share of $R \& D$ employees with both R\&D cooperations and the use of knowledge spillovers.

\section{Concluding Remarks}

Though knowledge spillovers play a widely recognized role in economic development, little attention has been paid to the innovation types stimulated by spillovers. This study provides 
evidence that firms exploit knowledge spillovers from rivals primarily for incremental product innovations which are closely related to the firms' already existing products. The finding highlights the crucial role of learning by doing. Other things equal, a firm has a higher absorptive capacity if it produces products that embody experience and know-how related to the rivals’ knowledge. As firms face difficulties in assimilating knowledge from areas they are not familiar with, spillovers are not normally used for drastic product innovations.

However, R\&D cooperations help to some degree to use spillovers even for drastic innovations. This indicates that $R \& D$ cooperations indeed provide opportunities for a very intensive and systematic exchange of information. This exchange of information has not only a direct positive impact on innovations but also an indirect influence by facilitating the use of knowledge spillovers.

Finally, our study highlights that it is important to distinguish between $R \& D$ cooperations and the firm's own $R \& D$ effort. While own $R \& D$ effort is an important input to the innovation process, our results do not provide evidence that it supports the use of outside information. Quite the contrary, there appear to be substitutive relationships between own R\&D effort and both R\&D cooperations and the use of knowledge spillovers. This indicates that research-intensive firms take a leading role in producing new knowledge. As they are operating at the frontier of product development, they have less to learn from others. Less research-intensive firms take a follower role. They specialize in learning from leaders and particularly adopt knowledge from the frontier which is useful for incremental innovations. 


\section{References}

Acemoglu, Daron, Philippe Aghion, and Fabrizio Zilibotti. 2006. “Distance to Frontier, Selection, and Economic Growth.” Journal of the European Economic Association, Forthcoming.

Arrow, Kenneth J. 1962. "Economic Welfare and the Allocation of Resources for Invention.” In Richard R. Nelson, ed., The Rate and Direction of Inventive Activity. Princeton: Princeton University Press, pp. 609-625.

Askildsen, Jan Erik, Uwe Jirjahn, and Stephen C. Smith. 2006. "Works Councils and Environmental Investment: Theory and Evidence from Germany." Journal of Economic Behavior and Organization, Forthcoming.

d'Aspremont, C., and A. Jacquemin. 1988. "Cooperative and Non-cooperative R\&D in Duopoly with Spillovers.” American Economic Review 78, pp. 1133-1137.

de Bondt, R. 1996. "Spillovers and Innovative Activities." International Journal of Industrial Organization 10, pp. 35-54.

Berman, E., J. Bound, and S. Machin. 1998. "Implications of Skill-Biased Technological Change: International Evidence.” Quarterly Journal of Economics 113, pp. 1245-1280.

Boone, J. 2000. "Competitive Pressure: the Effects on Investments in Product and Process Innovations.” RAND Journal of Economics 31, pp. 549-569.

Brand, R., V. Carstensen, K. Gerlach, and T. Klodt. 1996. “The Hannover Panel.” Discussion Paper No. 2, University of Hannover, Institute for Quantitative Economic Research.

Branstetter, Lee G., and Mariko Sakakibara. 1998. "Japanese Research Consortia: A Microeconometric Analysis of Industrial Policy.” Journal of Industrial Economics 46, pp. 207-233.

Brouwer, E., and A.H. Kleinknecht. 1997. “Measuring the Unmeasurable: A Country’s Non-R\&D Expenditure on Product and Service Innovation.” Research Policy 25, pp. 1235-1242.

Caloghirou, Yannis, Stavros Ioannides, and Nicholas S. Vonortas. 2003. "Research Joint Ventures.” Journal of Economic Surveys 17, pp. 541-570.

Czarnitzki, Dirk, and Kornelius Kraft. 2004. “Management Control and Innovative Activities.” Review of Industrial Organization 24, 1-24.

Cefis, E., and L. Orsenigo. 2001. “The Persistence of Innovative Activities: a Cross-Countries and 
Cross-Sectors Comparative Analysis.” Research Policy 30, pp. 1139-1158.

Cohen, W.M., and D.A. Levinthal. 1989. "Innovation and Learning: Two Faces of R\&D.” Economic Journal 99, pp. 569-596.

Dewar, Robert D., and Jane E. Dutton. 1986. “The Adoption of Radical and Incremental Innovations: An Empirical Analysis. ” Management Science 32, pp. 1422-1433.

Dewatripont, Mathias, Ian Jewitt, and Jean Tirole. 2000. "Multitask Agency Problems: Focus and Task Clustering.” European Economic Review 44, pp. 869-877.

Eeckhout, Jan, and Boyan Jovanovic. 2002. “Knowledge Spillovers and Inequality.” American Economic Review 92, pp. 1290-1307.

FitzRoy, Felix, and Kornelius Kraft. 1987. “Cooperation, Productivity and Profit Sharing.” Quarterly Journal of Economics 102, pp. 493-504.

Freeman, Richard B., and Edward P. Lazear. 1995. “An Economic Analysis of Works Councils.” in J. Rogers and W. Streeck, eds., Works Councils, Consultation, Representation, and Cooperation in Industrial Relations. Chicago: Chicago of University Press, pp. 27-52.

Gerlach, Knut, Olaf Hübler, and Wolfgang Meyer. 2003. "The Hannover Firm Panel (HFP)." Schmollers Jahrbuch - Journal of Applied Social Science Studies 123, pp. 463-470.

Gerlach, Knut, and Uwe Jirjahn. 2001. “Employer Provided Further Training: Evidence from German Establishment Data.” Schmollers Jahrbuch - Journal of Applied Social Science Studies 121, pp. 126.

Geroski, Paul. 1991. "Innovation and the Sectoral Sources of UK Productivity Growth.” Economic Journal 101, pp. 1438-1451.

Geroski, Paul, Steve Machin, and John Van Reenen. 1993. “The Profitability of Innovating Firms.” RAND Journal of Economics 24, pp. 198-211.

Greene, William. 2003. Econometric Analysis. Fifth Edition, New-Jersey, Prentice-Hall.

Grossman, G., and E. Helpman. 1990. “Trade, Innovation and Growth.” American Economic Review 80, pp. 86-91.

Hanel, Petr, and Alain St-Pierre. 2002. "Effects of R\&D Spillovers on the Profitability of Firms." Review of Industrial Organization 20, pp. 305-322. 
Harhoff, D. 1999. "Innovation Objectives, Managerial Education and Firm Performance - An Exploratory Analysis.” in K. Brockhoff, A.K. Chakrabarti and J. Hauschildt, eds., The Dynamics of Innovation - Strategic and Managerial Implications. Springer, pp. 137-160.

Hübler, Olaf, and Uwe Jirjahn. 2003. "Works Councils and Collective Bargaining in Germany: The Impact on Productivity and Wages.” Scottish Journal of Political Economy 50, pp. 1-22.

Hunt, Jennifer. 1999. “Has Work Sharing Worked in Germany?” Quarterly Journal of Economics 114, pp. 117-148.

Ichniowski, Casey, and Kathryn Shaw. 1995. “Old Dogs and New Tricks: Determinants of the Adoption of Productivity-Enhancing Work Practices.” In M. Baily, P. Reiss, and C. Winston, eds., Brookings Papers on Economic Activity. Washington D.C.: Brookings Institution, pp. 1-65.

Jirjahn, Uwe. 2000. “Incentives for Multitasking: Fixed Wages or Profit Sharing?” Economic Analysis 3, pp. 137-148.

Jovanovic, Boyan, and Glenn M. MacDonald. 1994. "Competitive Diffusion.” Journal of Political Economy 102, pp. 24-52.

Kamien, Morton I., and Israel Zang. 2000. "Meet Me Halfway: Research Joint Ventures and Absorptive Capacity.” International Journal of Industrial Organization 18, pp. 995-1012.

Katsoulacos, Yannis, and David Ulph. 1998. "Endogenous Spillovers and the Performance of Research Joint Ventures.” Journal of Industrial Economcis 48, pp. 333-357.

Kleinknecht, A.H. 1987. “Measuring R\&D in Small Firms: How Much Are We Missing?” Journal of Industrial Economics 36, pp.253-256.

Knott, Anne Marie. 2003. "Persistent Heterogeneity and Sustainable Innovation.” Strategic Management Journal 24, 687-705.

Knott, Anne Marie, Brian Wu, and Hart Posen. 2004. “Spillover Asymmetry.” Working Paper, University of Maryland.

Laursen, Keld, and Nicolai J. Foss. 2003. "New Human Resource Management Practices, Complementarities and the Impact on Innovation Performance.” Cambridge Journal of Economics $27,243-263$.

Levin, R.C. 1988. “Appropriability, R\&D Spending, and Technological Performance.” American 
Economic Review 78, pp. 424-428.

Lindbeck, Assar, and Dennis Snower. 2001. “Centralized Bargaining and Reorganized Work: Are They Compatible?” European Economic Review 45, pp. 1851-1875.

Martin, S. 1993. "Endogenous Firm Efficiency in a Cournot Principal-Agent Model.” Journal of Economic Theory 59, pp. 445-450.

Menezes-Filho, David Ulph, and John Van Reenen. 1998. “The Determination of R\&D: Empirical Evidence on the Role of Unions.” European Economic Review 42, 919-930.

Milgrom, Paul, and John Roberts. 1995. "Continuous Adjustment and Fundamental Change in Business Strategy and Organization.” In Horst Siebert, ed., Trends in Business Organization: Do Participation and Cooperation Increase Competitiveness? Tübingen: Mohr, pp. 231-258.

Nelson, R.R. 1959. “The Simple Economics of Basic Scientific Research.” Journal of Political Economy 67, pp. 297-306.

Nickell, S., and D. Nicolitsas. 2000. "Human Capital, Investment and Innovation: What Are the Connections?” In R. Barrel, G. Mason, and O’ Mahoney, eds., Productivity, Innovation and Economic Performance, Cambridge: Cambridge University Press.

Oulton, N. 1998. "Competition and the Dispersion of Labour Productivity amongst UK Companies.” Oxford Economic Papers 50, pp. 23-38.

Peters, J. 2000. "Buyer Market Power and Innovative Activities.” Review of Industrial Organization 16, pp. 13-38.

Peters, J., and W. Becker. 1998. “Technological Opportunities, Academic Research, and Innovation Activities in the German Automobile Industry.” Working Paper, University of Augsburg.

Röller, Lars-Hendrik, and Bernard Sinclair-Desgagnè. 1996. "On the Heterogeneity of Firms.” European Economic Review 40, pp. 531-539.

Romer, P.M. 1986. “Increasing Returns and Long-Run Growth.” Journal of Public Economics 94, pp. 1002-1037.

Schmidt, K.M. 1997. "Managerial Incentives and Product Market Competition.” Review of Economic Studies 64, pp. 191-213.

Sena, Vania. 2004. "The Return of the Prince of Denmark: A Survey on Recent Developments in the 
Economics of Innovation.” Economic Journal 114, pp. F312-F332.

Smith, Stephen C. 1994. "Innovation and Market Strategy in Italian Industrial Cooperatives: Econometric Evidence on Organizational Comparative Advantage.” Journal of Economic Behavior and Organization 23, pp. 303-321.

Spence, Michael A. 1981. “The Learning Curve and Competition.” Bell Journal of Economics 12, pp. 49-70.

Teece, David J., Richard Rumelt, Giovanni Dosi, and Sidney Winter. 1994. "Understanding Corporate Coherence: Theory and Evidence.” Journal of Economic Behavior and Organization 23, pp. 1-30.

Zwick, Thomas. 2002. “Employee Resistance against Innovations.” International Journal of Manpower 23, pp. 542-552. 
Table 1: Variable Definitions and Descriptive Statistics

\begin{tabular}{|c|c|}
\hline Variable & Description (mean, standard deviation) \\
\hline FOLLPROD & Dummy variable equal to 1 if the establishment launched follow-up products $(.330, .470)$. \\
\hline QUALPROD & $\begin{array}{l}\text { Dummy variable equal to } 1 \text { if the establishment launched qualitatively improved products } \\
(.337, .473) \text {. }\end{array}$ \\
\hline FUNCPROD & $\begin{array}{l}\text { Dummy variable equal to } 1 \text { if the establishment launched products with additional } \\
\text { functions }(.202, .401) \text {. }\end{array}$ \\
\hline NEWPROD & $\begin{array}{l}\text { Dummy variable equal to } 1 \text { if the establishment launched completely new products (.223, } \\
\text {.417). }\end{array}$ \\
\hline PATENT & Dummy variable equal to 1 if the establishment filed patents $(.160, .367)$ \\
\hline RIVALIDEA & $\begin{array}{l}\text { Dummy variable equal to } 1 \text { if the establishment normally gets its ideas for product } \\
\text { innovations from observing competitors }(.455, .498) \text {. }\end{array}$ \\
\hline RESEARCH & Dummy variable equal to 1 if $R \& D$ is institutionalized in the establishment $(.501, .500)$. \\
\hline RESEARCHSTAFF & Employees involved in R\&D as a proportion of total employees $(.031, .053)$. \\
\hline RESEARCHCOOP & $\begin{array}{l}\text { Dummy variable equal to } 1 \text { if the establishment has R\&D cooperations with other firms } \\
\text { or institutions }(.436, .496) \text {. }\end{array}$ \\
\hline RESEARCHSTAFF*RESEARCHCOOP & RESEARCHSTAFF interacted with RESEARCHCOOP $(.0263, .050)$ \\
\hline RESEARCHSTAFF*RIVALIDEA & RESEARCHSTAFF interacted with RIVALIDEA $(.015, .040)$ \\
\hline RESEARCHCOOP*RIVALIDEA & RESEARCHCOOP interacted with RIVALIDEA $(.235, .424)$ \\
\hline MANAGERIDEA & $\begin{array}{l}\text { Dummy variable equal to } 1 \text { if ideas from executive managers or establishment owners } \\
\text { play an important role in developing products }(.519, .500) \text {. }\end{array}$ \\
\hline MARKETINGIDEA & $\begin{array}{l}\text { Dummy variable equal to } 1 \text { if ideas from the establishment's marketing department play } \\
\text { an important role in developing products }(.193, .395) \text {. }\end{array}$ \\
\hline CUSTOMERIDEA & $\begin{array}{l}\text { Dummy variable equal to } 1 \text { if ideas from customers play an important role in developing } \\
\text { products }(.788, .409) \text {. }\end{array}$ \\
\hline CUSTOMERSPECIALIZE & $\begin{array}{l}\text { Dummy variable equal to } 1 \text { if the establishment concentrates on a particular customer } \\
\text { group }(.297, .457) \text {. }\end{array}$ \\
\hline SALESMAINPRODUCT & $\begin{array}{l}\text { Ordered variable for the percentage of sales attributed to the main product group; } 1=\text { less } \\
\text { than } 20 \%, \ldots, 5=\text { at least } 80 \%(3.75,1.19) .\end{array}$ \\
\hline PRESSURE & $\begin{array}{l}\text { Dummy variable equal to } 1 \text { if management feels that the pressure by competitors is very } \\
\text { high }(.585, .493) \text {. }\end{array}$ \\
\hline EXPORT & Percentage of the establishment's sales generated by exports $(14.94,21.20)$. \\
\hline TEAM & $\begin{array}{l}\text { Dummy variable equal to } 1 \text { if at least } 10 \% \text { of the blue-collar workers in the establishment } \\
\text { are organized in production teams with expanded autonomy and multiple responsibilities } \\
(.349, .477) \text {. }\end{array}$ \\
\hline PROFITSHARING & $\begin{array}{l}\text { Dummy variable equal to } 1 \text { if the establishment provides profit sharing to employees } \\
\text { other than executives }(.169, .375) \text {. }\end{array}$ \\
\hline BLUECOLLAR & Blue-collar workers as a proportion of total employees $(.621, .186)$. \\
\hline UNIVERSITY & University and college graduates as a proportion of total employees $(.036, .049)$. \\
\hline TRAINING & $\begin{array}{l}\text { Dummy variable equal to } 1 \text { if the establishment finances continuous training for the } \\
\text { employees }(.578, .494) \text {. }\end{array}$ \\
\hline WORKSCOUNCIL & Dummy variable equal to 1 if a works council is present in the establishment $(.585, .493)$. \\
\hline COLLECTBARGAin & $\begin{array}{l}\text { Dummy variable equal to } 1 \text { if the establishment is covered by a collective bargaining } \\
\text { agreement }(.661, .473) .\end{array}$ \\
\hline SIZE & Total employees in the establishment (164.06, 558.71). \\
\hline SIZESQUARED & Total employees in the establishment squared \\
\hline SHIFTWORK & Dummy variable equal to 1 if the establishment uses shift work $(.440, .497)$. \\
\hline TECHNEW & $\begin{array}{l}\text { Dummy variable equal to } 1 \text { if the production technology is of the most recent vintage } \\
(.347, .476) \text {. }\end{array}$ \\
\hline WOMEN & Women as a proportion of total employees $(.288, .232)$. \\
\hline 1996 & Time dummy for $1996(.469, .499)$. \\
\hline INDUSTRYDUMMIES & Dummy variables for 14 broad industrial groups in the manufacturing sector. \\
\hline Observations & 1022 \\
\hline
\end{tabular}


Table 2: Initial Regression Results without Control Variables for R\&D and Cooperations in R\&D; Method: Multivariate Probit

\begin{tabular}{|c|c|c|c|c|c|c|c|c|c|c|}
\hline \multirow{2}{*}{$\begin{array}{l}\text { Dependent Variable } \\
\text { Explanatory Variable }\end{array}$} & \multicolumn{2}{|c|}{ FOLLPROD } & \multicolumn{2}{|c|}{ Q QUALPROD } & \multicolumn{2}{|c|}{ "FUNCPROD } & \multicolumn{2}{|c|}{ INEWPROD } & \multicolumn{2}{|c|}{ PATENT } \\
\hline & $\hat{\beta}$ & $|t|$ & $\hat{\beta}$ & $|t|$ & $\hat{\beta}$ & $|t|$ & $\hat{\beta}$ & $|t|$ & $\hat{\beta}$ & $|t|$ \\
\hline RIVALIDEA & .2199 & $(2.43)^{* *}$ & .2425 & $(2.62)^{* * *}$ & .0942 & (0.95) & -.0243 & $(0.25)$ & -.0705 & $(0.61)$ \\
\hline MANAGERIDEA & .1048 & $(1.17)$ & .2355 & $(2.58) * *$ & .2732 & $(2.76)^{* * *}$ & .2762 & $(2.86)^{* * *}$ & .1001 & $(0.88)$ \\
\hline MARKETINGIDEA & .3367 & $(2.96)^{* * *}$ & .1951 & $(1.66)^{*}$ & .3269 & $(2.61)^{* * *}$ & .1446 & (1.19) & .1785 & $(1.31)$ \\
\hline CUSTOMERIDEA & .2894 & $(2.56)^{* *}$ & .2877 & $(2.51)^{* *}$ & .1282 & $(1.00)$ & .0569 & $(0.47)$ & .2345 & $(1.40)$ \\
\hline CUSTOMERSPECIALIZE & -.0433 & $(0.45)$ & -.2072 & $(2.04) * *$ & -.0563 & $(0.52)$ & -.1127 & (1.09) & -.2165 & $(1.70)^{*}$ \\
\hline SALESMAINPRODUCT & -.1206 & $(3.26)^{* * *}$ & -.0321 & $(0.87)$ & -.0011 & $(0.03)$ & -.1082 & $(2.74)^{* * *}$ & -.0056 & $(0.13)$ \\
\hline PRESSURE & -.1359 & $(1.53)$ & -.2002 & $(2.19)^{* *}$ & -.0987 & $(0.98)$ & -.2147 & $(2.27)^{* *}$ & -.1527 & $(1.32)$ \\
\hline EXPORT & .0019 & $(0.80)$ & .0080 & $(3.40)^{* * *}$ & .0043 & $(1.78)^{*}$ & .0018 & $(0.74)$ & .0092 & $(3.46)^{* * *}$ \\
\hline TEAM & -.0774 & $(0.84)$ & .1022 & (1.08) & .2099 & $(2.02)^{* *}$ & .2560 & $(2.63)^{* * *}$ & -.2849 & $(2.33)^{* *}$ \\
\hline PROFITSHARING & .1268 & $(1.11)$ & .0948 & $(0.85)$ & .0787 & $(0.64)$ & .1192 & $(0.99)$ & .3295 & $(2.44)^{* *}$ \\
\hline BLUECOLLAR & -.6072 & $(2.36)^{* *}$ & -.4030 & $(1.52)$ & -.2581 & $(0.84)$ & .0412 & $(0.14)$ & -.8784 & $(2.46)^{* *}$ \\
\hline UNIVERSITY & .6740 & $(0.64)$ & -.0912 & $(0.08)$ & -.5302 & $(0.47)$ & -.8788 & $(0.84)$ & 1.8056 & $(1.71)^{*}$ \\
\hline TRAINING & .0054 & $(0.05)$ & .2175 & $(2.10)^{* *}$ & .2327 & $(2.08)^{* *}$ & .1914 & $(1.75)^{*}$ & .2818 & $(2.20)^{* *}$ \\
\hline WORKSCOUNCIL & .2264 & $(1.93)^{*}$ & .0956 & $(0.80)$ & .4672 & $(3.60)^{* * *}$ & .0751 & $(0.61)$ & -.0661 & $(0.44)$ \\
\hline COLLECTBARGAIN & -.1785 & $(1.71)^{*}$ & -.0758 & $(0.72)$ & -.2750 & $(2.30)^{* *}$ & -.1819 & $(1.66)^{*}$ & -.3379 & $(2.53)^{* *}$ \\
\hline SIZE & .0009 & $(2.62)^{* * *}$ & .0009 & $(3.63)^{* * *}$ & .0005 & $(2.00)^{* *}$ & $-2 \cdot 10^{-5}$ & $(0.08)$ & .0010 & $(2.12)^{* *}$ \\
\hline SIZESQUARED & $-9 \cdot 10^{-8}$ & $(1.97)^{* *}$ & $-7 \cdot 10^{-8}$ & $(4.06)^{* * *}$ & $-4 \cdot 10^{-8}$ & $(2.22)^{* *}$ & $-2 \cdot 10^{-8}$ & $(0.39)$ & $-2 \cdot 10^{-7}$ & $(1.05)$ \\
\hline SHIFTWORK & .2300 & $(2.02)^{* *}$ & .1199 & $(1.08)$ & .1557 & $(1.26)$ & .2060 & $(1.71)^{*}$ & .6469 & $(4.50)^{* * *}$ \\
\hline TECHNEW & -.0359 & $(0.38)$ & .0252 & $(0.27)$ & .0846 & $(0.83)$ & -.1072 & $(1.06)$ & .1263 & $(1.10)$ \\
\hline WOMEN & .3593 & $(1.53)$ & .7082 & $(2.73)^{* * *}$ & -.1097 & $(0.39)$ & .7441 & $(2.92)^{* * *}$ & -.1793 & $(0.56)$ \\
\hline 1996 & .0104 & $(0.12)$ & .1056 & $(1.20)$ & .1034 & $(1.09)$ & .0932 & $(1.00)$ & .0004 & $(0.00)$ \\
\hline CONSTANT & -.7126 & $(2.08)^{* *}$ & -1.6989 & $(4.75)^{* * *}$ & -1.7951 & $(4.65)^{* * *}$ & -1.2625 & $(3.24)^{* * *}$ & -1.3587 & $(3.08)^{* * *}$ \\
\hline INDUSTRYDUMMIES & Yes & & Yes & & Yes & & Yes & & Yes & \\
\hline $\log L$ & -2259.5 & & & & & & & & & \\
\hline Correlation of Error Terms & $\begin{array}{l}\text { Rho21 } \\
\text { Rho42 }\end{array}$ & $\begin{array}{l}6051(14.72) \\
1955(3.56)^{*}\end{array}$ & $\begin{array}{l}\text { Rho31 }=.40 \\
\text { Rho52 }=.023\end{array}$ & $\begin{array}{l}(7.73) * * *, 1 \\
0.37), \text { Rho4. }\end{array}$ & $\begin{array}{l}1=.2148(3 . \\
388(4.30)^{* *}\end{array}$ & $\begin{array}{l}* * *, \text { Rho51 } \\
\text { Rho53 = .1 }\end{array}$ & $\begin{array}{l}55(2.17)^{*} \\
.55)^{* *}, R h\end{array}$ & $\begin{array}{l}h o 32=.480 \\
=.1855(2 .\end{array}$ & $10)^{* * *}$ & \\
\hline Observations & 1022 & & & & & & & & & \\
\hline
\end{tabular}


Table 3: Regression Results with a Control Variable for R\&D; Method: Multivariate Probit

\begin{tabular}{|c|c|c|c|c|c|c|c|c|c|c|}
\hline \multirow{2}{*}{$\begin{array}{l}\text { Dependent Variable } \\
\text { Explanatory Variable }\end{array}$} & \multicolumn{2}{|c|}{ FOLLPROD } & \multicolumn{2}{|c|}{ "QUALPROD } & \multicolumn{2}{|c|}{ "FUNCPROD } & \multicolumn{2}{|c|}{ "NEWPROD } & \multicolumn{2}{|c|}{ PATENT } \\
\hline & $\hat{\beta}$ & $|t|$ & $\hat{\beta}$ & $|t|$ & $\hat{\beta}$ & $|t|$ & $\hat{\beta}$ & $|t|$ & $\hat{\beta}$ & $|t|$ \\
\hline RIVALIDEA & .2084 & $(2.29)^{* *}$ & .2333 & $(2.50)^{* *}$ & .0773 & $(0.77)$ & $\begin{array}{l}.0538 \\
\end{array}$ & (0.25) & $\begin{array}{l}.0882 \\
\end{array}$ & $(0.75)$ \\
\hline RESEARCH & .4097 & $(3.87) * * *$ & .4700 & $(4.42)^{* * *}$ & .4873 & $(4.03)^{* * *}$ & .5926 & $(5.06)^{* * *}$ & .8671 & $(5.86) * * *$ \\
\hline
\end{tabular}

LogL -2217.26

Correlation of Error Terms

Rho21 = .5980 (14.24)***, Rho31 = .3941 (7.34)***, Rho41 = .1910 (3.36)***, Rho51 = .1152 (1.55), Rho32 = .4685 (9.58)***, Rho42 = .1696 (3.01)***, Rho52 = -.0332 (0.50), Rho43 = .2163 (3.81)***, Rho53 = .1385 (1.97)**, Rho54 = .1046 (1.44)

Observations 1022

Note that all of the other control variables listed in Table 2 are included but are suppressed to save space. Robust T-statistics in parentheses. *Statistically significant at the .10 level.

**Statistically significant at the .05 level. ***Statistically significant at the .01 level.

Table 4: Regression Results with Control Variables for Research Cooperations and R\&D Intensity; Method: Multivariate Probit

\begin{tabular}{|c|c|c|c|c|c|c|c|c|c|c|}
\hline \multirow{2}{*}{$\begin{array}{l}\text { Dependent Variable } \\
\text { Explanatory Variable }\end{array}$} & \multicolumn{2}{|c|}{ FOLLPROD } & \multicolumn{2}{|c|}{ QQUALPROD } & \multicolumn{2}{|c|}{ FINCPROD } & \multicolumn{2}{|c|}{ NEWPROD } & \multicolumn{2}{|c|}{ PATENT } \\
\hline & $\hat{\beta}$ & $|t|$ & $\hat{\beta}$ & $|t|$ & $\hat{\beta}$ & $|t|$ & $\hat{\beta}$ & $|t|$ & $\hat{\beta}$ & $|t|$ \\
\hline RIVALIDEA & .2048 & $(2.25)^{* *}$ & .2305 & $(2.46)^{* *}$ & .0616 & $(0.47)$ & -.0326 & $(0.34)$ & -.0870 & $(0.74)$ \\
\hline RESEARCHCOOP & .4211 & $(3.68)^{* * *}$ & .4530 & $(3.96)^{* * *}$ & .3788 & $(2.96) * * *$ & .2388 & $(1.93)^{*}$ & .7189 & $(5.02)^{* * *}$ \\
\hline RESEARCHSTAFF & -.5942 & $(0.56)$ & -.2016 & $(0.18)$ & 1.0605 & $(0.87)$ & 3.5186 & $(3.00)^{* * *}$ & 1.0441 & $(0.93)$ \\
\hline
\end{tabular}

LogL

Correlation of Error Terms

Rho21 = .5949 $(14.10)^{* * *}$, Rho31 $=.3974(7.38)^{* * *}$, Rho41 = .2092 (3.71)***, Rho51 = .1128 (1.57), Rho32 = .4696 (9.63)***,

Rho42 = .1825 (3.26)***, Rho52 = -.0280 (0.43), Rho43 = .2238 (3.95)***, Rho53 = .1297 (1.87)*, Rho54 = .1235 (1.66)*

Observations

1022

Note that all of the other control variables listed in Table 2 are included but are suppressed to save space. Robust T-statistics in parentheses. *Statistically significant at the .10 level.

**Statistically significant at the .05 level. ***Statistically significant at the .01 level.

Table 5a: Regression Results with Control Variables for Research Cooperations, R\&D Intensity and Interaction Effects; Method: Multivariate Probit 


\begin{tabular}{|c|c|c|c|c|c|c|c|c|c|c|}
\hline \multirow{2}{*}{$\begin{array}{c}\text { Dependent Variable } \\
\text { Explanatory Variable }\end{array}$} & \multicolumn{2}{|c|}{ FOLLPROD } & \multicolumn{2}{|c|}{ QUALPROD } & \multicolumn{2}{|c|}{ FUNCPROD } & \multicolumn{2}{|c|}{ NEWPROD } & \multicolumn{2}{|c|}{ PATENT } \\
\hline & $\hat{\beta}$ & $|t|$ & $\hat{\beta}$ & $|t|$ & $\hat{\beta}$ & $|t|$ & $\hat{\beta}$ & $|t|$ & $\hat{\beta}$ & $|t|$ \\
\hline RIVALIDEA & .2340 & $(1.88)^{*}$ & .1013 & $(0.76)$ & .2669 & $(1.78)^{*}$ & -.0883 & $(0.62)$ & -.0638 & $(0.29)$ \\
\hline RESEARCHCOOP & .5402 & $(3.21)^{* * *}$ & .3549 & $(2.15)^{* *}$ & .5129 & $(2.82)^{* * *}$ & .0645 & $(0.36)$ & .6868 & $(3.13)^{* * *}$ \\
\hline RESEARCHSTAFF & 2.906 & $(1.49)$ & 4.465 & $(2.23)^{* *}$ & 6.625 & $(3.15)^{* * *}$ & 9.137 & $(4.06)^{* * *}$ & 2.584 & $(1.17)$ \\
\hline RESEARCHSTAFF*RESEARCHCOOP & -4.322 & $(1.98)^{* *}$ & -4.459 & $(2.08)^{* *}$ & -4.887 & $(2.12)^{* *}$ & -3.486 & $(1.43)$ & -.3743 & $(0.15)$ \\
\hline RESEARCHCOOP*RIVALIDEA & -.0409 & $(0.20)$ & .4068 & $(1.99)^{* *}$ & -.0459 & $(0.21)$ & .5118 & $(2.32)^{* *}$ & .1282 & $(0.46)$ \\
\hline RESEARCHSTAFF*RIVALIDEA & -.3311 & $(0.17)$ & -2.373 & (1.29) & -3.771 & $(1.84)^{*}$ & -5.892 & $(2.90)^{* * *}$ & -2.514 & $(1.22)$ \\
\hline
\end{tabular}

LogL

Correlation of Error Terms

Rho21 = .5992 (14.30)***, Rho31 = .4015 (7.50)***, Rho41 = .2125 (3.73)***, Rho51 = .1107 (1.55), Rho32 = .4759 (9.67)***, Rho42 = .1797 (3.19)***, Rho52 = -.0257 (0.39), Rho43 = .2224 (3.89)***, Rho53 = .1329 (1.90)*, Rho54 = .1229 (1.67)*

Observations 1022

Note that all of the other control variables listed in Table 2 are included but are suppressed to save space. Robust T-statistics in parentheses. *Statistically significant at the .10 level.

**Statistically significant at the .05 level. ***Statistically significant at the .01 level.

Table 5b: Regression Results with Control Variables for Research Cooperations, R\&D Intensity and Interaction Effects; Method: Multivariate Probit

\begin{tabular}{|c|c|c|c|c|c|c|c|c|c|c|}
\hline \multirow{2}{*}{$\begin{array}{l}\text { Dependent Variable } \\
\text { Explanatory Variable }\end{array}$} & \multicolumn{2}{|c|}{ FOLLPROD } & \multicolumn{2}{|c|}{ QUALPROD } & \multicolumn{2}{|c|}{ FUNCPROD } & \multicolumn{2}{|c|}{ NEWPROD } & \multicolumn{2}{|c|}{ PATENT } \\
\hline & $\hat{\beta}$ & $|t|$ & $\hat{\beta}$ & $|t|$ & $\hat{\beta}$ & $|t|$ & $\hat{\beta}$ & $|t|$ & $\hat{\beta}$ & $|t|$ \\
\hline RIVALIDEA & .2083 & $(2.29)^{* *}$ & .0881 & $(0.70)$ & .2448 & $(2.06)^{* *}$ & -.0928 & $(0.66)$ & -.0670 & $(0.31)$ \\
\hline RESEARCHCOOP & .5215 & $(4.13)^{* * *}$ & .3454 & $(2.20)^{* *}$ & .4889 & $(3.54)^{* * *}$ & .0601 & $(0.34)$ & .6416 & $(3.33)^{* * *}$ \\
\hline RESEARCHSTAFF & 2.804 & (1.49) & 4.441 & $(2.21)^{* *}$ & 6.632 & $(3.13)^{* * *}$ & 9.121 & $(4.10)^{* * *}$ & 2.315 & $(1.65)^{*}$ \\
\hline RESEARCHSTAFF*RESEARCHCOOP & -4.364 & $(2.07)^{* *}$ & -4.473 & $(2.10)^{* *}$ & -4.830 & $(2.12)^{* *}$ & -3.470 & $(1.44)$ & --- & --- \\
\hline RESEARCHCOOP*RIVALIDEA & --- & --- & .4281 & $(2.43)^{* *}$ & --- & --- & .5203 & $(2.38)^{* *}$ & .1388 & $(0.50)$ \\
\hline RESEARCHSTAFF*RIVALIDEA & --- & --- & -2.286 & $(1.36)$ & -3.857 & $(2.21)^{* *}$ & -5.876 & $(2.91)^{* * *}$ & -2.586 & $(1.30)$ \\
\hline
\end{tabular}

LogL $-2203.53 \quad-2.286$

Correlation of Error Terms $\quad$ Rho21 $=.5989(14.28)^{* * *}$, Rho31 $=.4017(7.50)^{* * *}$, Rho41 = .2123 (3.73)***, Rho51 = .1111 $(1.56)$, Rho32 =.4759 $(9.68)^{* * *}$,

Rho42 = .1796 (3.19)***, Rho52 = -.0256 (0.39), Rho43 = .2226 (3.90)***, Rho53 = .1328 (1.89)*, Rho54 = .1235 (1.67)*

Observations

1022

Note that all of the other control variables listed in Table 2 are included but are suppressed to save space. Robust T-statistics in parentheses. *Statistically significant at the .10 level.

${ }^{* *}$ Statistically significant at the .05 level. ${ }^{* * *}$ Statistically significant at the .01 level. 


\section{Endnotes}

${ }^{1}$ Zwick (2002) provides empirical evidence for employee resistance against innovations.

${ }^{2}$ See Dewatripont, Jewitt and Tirole (2000) for a theoretical principal-agent analysis of the coherence of activities.

${ }^{3}$ See Röller and Sinclair-Desgagnè (1996) for a theoretical analysis of heterogenous firms. Empirical evidence on the heterogeneity of firms is provided by Oulton (1998).

${ }^{4}$ Findings by Cefis and Orsenigo (2001) indicate that the continuous accumulation of resources and competencies play a more important role than the size of R\&D expenditures in maintaining innovative activities. This may also apply to the use of knowledge spillovers.

${ }^{5}$ Such a specialization may also hold in an international context with respect to backward countries and advanced countries. Acemoglu, Aghion and Zilibotti (2006) argue that firms in relatively backward economies invest in adopting existing technologies from the world frontier. Firms in advanced economies, that are closer to the world-technology frontier, pursue a research-based strategy.

${ }^{6}$ Details of the data set and how it can be accessed by researchers are given in Gerlach, Hübler and Meyer (2003). A complete copy of the questionnaire is available in Brand et al. (1996).

${ }^{7}$ Since the survey is based on the voluntary participation of establishments, the decline in sample size is not unusual. For the establishments not participating in the subsequent waves one main reason was that time limitations hindered participation.

${ }^{8}$ The type of restrictions imposed by collective bargaining in Germany remains a matter of debate. Lindbeck and Snower (2001) speculate that centralized collective bargaining is unavoidably incompatible with a flexible assignment of tasks within establishments as it follows the rule "equal pay for equal work” involving a standardization of wages and jobs. However, German unions just may have embarked on a wrong strategy. In the eighties, they began to reduce standard weekly hours, resulting in restrictions on working time flexibility (Hunt, 1999).

${ }^{9}$ The estimates were performed in STATA 8.0 using a program written by Lorenzo Capellari and Stephen P. Jenkins.

10 Note that we also experimented with an interaction of all three key variables, i.e. RESEARCHSTAFF*RIVALIDEA*RESEARCHCOOP. Yet, it did not emerge as a significant determinant. 
${ }^{11}$ E.g., let us consider the launch of products with additional functions, FOLLPROD. If an establishment has no R\&D employees (RESEARCHSTAFF $=0)$, the influence of $\mathrm{R} \& \mathrm{D}$ cooperation $($ RESEARCHCOOP $=$ 1) on the underlying latent variable is equal to 0.489 . Let us now consider a second establishment that has a share of R\&D employees equal to the mean in our sample $($ RESEARCHSTAFF $=0.031)$. While the share of R\&D employees has a direct positive influence $\left(0.205=6.625^{*} 0.031\right)$, it also has an indirect negative effect $(-0.151=-4.887 * 0.031 * 1)$ by reducing the influence of $R \& D$ cooperations. Thus in the second establishment, the net effect of $R \& D$ cooperation is only equal to $0.489-0.151$ or 0.338 . 